\title{
SENGHOR, GLOBALISM AND AFRICANITY
}

\author{
Malesela John Lamola \\ University of Fort Hare \\ Jlamola@mweb.co.za
}

\section{ABSTRACT}

A reflection on the challenges of African identity within the context of the persistence of European Modernity as the ideal of globalisation offers an opportunity for a fresh perspective on the life and work of Léopold Sédar Senghor. We subject Senghor's life and intellectual output to a critical triangular prism of: (1) Paul James's critique of globalism as an ideology of globalisation; (2) Walter Mignolo's enunciation of the epistemico-cultural implications of Western-led globalisation on the postcolony; and (3) Paulin Houtondji's Afrocentric critical literary theory. The result is a claim we make that in the devotion of his literary talent and intellectual prowess to the nurturing of the 'French way', Senghor not only nurtured an imperialistic French globalism, but betrayed an opportunity to assert a political space for an enduring decolonial African epistemology during a critical period in the history of Africa's relationship with Europe. Senghor's life praxis is in this way presented as a typology of the psychopolitical pitfalls facing African thought leaders in their postcolonial engagement with Western modernity.

Keywords: African political philosophy; Africanity; decoloniality; exogeneity; globalism; postcoloniality; Senghor

\section{INTRODUCTION: SENGHOR THE PROBLEM}

The life and thought of Léopold Sédar Senghor (1906-2001), one of the most celebrated African literary-philosophers acculturated into the French educational and political system, and still able to retain a modicum of postcolonial revolutionary impact, constitute an interesting case and fulcrum of enquiry on the appropriate postcolonial expression of African identity.

\section{UNISA $\cong$}


Senghor, the anti-colonial intellectual and founding President of the Republic of Senegal from 1961 to 1981, boasts a uniquely controversial profile. His biographers, both critical and complementary (Hymans 1971; Vaillant 1990) agree that he was a product of the best that the French colonial policy of assimilation of colonial subjects into the French cultural system could produce. His articulation of Negritude has variously been criticised as ambiguous (Irele 2002: 112), and his stand on key programmes on the agenda of the liberation and renaissance of Africa, as this paper aims to point out, ambivalent.

In his autobiography, No easy walk to freedom, Nelson Mandela (1994) narrates some very pertinent impressions he framed on Senghor, the man he describes as "a scholar and poet”. In 1962 Mandela left South Africa without a passport on a mission that took him to several newly independent African countries to raise funds and make arrangements for military training for the launch of the African National Congress's nascent military wing. He reports that as his itinerary approached Senegal: "I have been told to be wary of Senghor, for there were reports that Senegalese soldiers were serving with the French in Algiers, and that he was a bit too taken with the customs and charms of the ancient regime" (Mandela 1994: 358). Mandela proceeds to tell how disappointing their meeting was, but how above all he was concerned at the extent to which President Senghor had confidence in the French members of his civil service. Senghor, according to Mandela, allayed his expressed discomfort at this with a statement: "Mandela, do not worry, the French here identify themselves completely with our African aspirations" (Mandela 1994: 359).

A native of the rural village of Joal on the outskirts of Dakar, Senghor consciously allowed himself to become French, actively adored things French, and later, influenced by his poetic vocation, sought to fashion the spiritual and psychological discord emanating from a clash between his African cultural roots and his French acculturation into a tool for the liberation of African selfhood from colonial disfiguration. This, our paper aims to show, rendered him a champion of an adventurist cultural theory that advocates the cross-fertilisation and symbiosis of colonial and postcolonial cultural systems without questioning the globalistic assumptions of the former.

In October 1996 the United Nations Education Scientific and Cultural Organisation (UNESCO) hosted a three-day celebration of Senghor's ninetieth birthday. The Director-General, Frederico Mayor, introduced Senghor as not only a "teacher, statesman, philosopher, wise man of Africa, Serer peasant, bard of negritude", but also as "a theorist of cultural dialogue", thus drawing attention to the fact that much of Senghor's intellectual conduct was a conscious enactment of some theory of cultural fraternity amongst diverse nationalities. In his congratulatory message at the same event, which was co-hosted with the Agence univeritaire de la

1 http://unesdoc.unesco.org/images/0010/001044/104487e.pdf (accessed 20 October 2014). 
Francophonie, French President Jacque Chirac added that Senghor's name "is the symbol of generosity, dialogue and hope" for the world community. ${ }^{2}$

In 1983, two years after retiring from a 20-year tenure as President of the Republic of Senegal, Senghor was elected to L'Académie française. He became the first black African to be inducted as one of the les immortels (the French intellectual immortals) of the more than 350-years old academy (Dixon, in Senghor 1991: xxi). This prestigious French Academy - to which only the most distinguished French intellectuals are nominated - has as its primary mission the promotion and monitoring of the development of the French language and culture globally. This gesture and honour, besides being the epitome of a number of politically startling appointments and achievements Senghor attained within French society, is, in our view, a summative indication of the intellectual character of his persona.

He was a product of a uniquely French approach to the colonisation of Africa, and remains entombed in the annals of the history of modern Africa as the paragon of this policy, the policy of assimilation. Arising from the historico-cultural commitment to the revolutionary mantra of liberté, équalité, fraternité, French colonial philosophy in Africa, unlike the British and Portuguese, believed that there was among the colonised a potential elite that French education and tutelage could guide into being culturally transformed into Frenchmen (Khaphoya 1994: 121-124). Though premised on an assumption of the inferiority of the African way of life, this colonial philosophy held that Africans have the rational potential of being civilised and upgraded into European beings. Culture, rather than racial ancestry served as the fundamental ingredient of "Frenchness".

As we demonstrate later on, Senghor, the revolutionary, became an assimilador par excellence. He became what Jean-Paul Sartre eloquently describes in his preface to Franz Fanon's The wretched of the Earth (1961: 7) with these words:

The European elite undertook to manufacture a native elite. They picked the promising adolescents; they branded them, as with a red-hot iron with the principles of Western culture; they stuffed their mouths full with high-sounding phrases, grand glutinous words that stuck to the teeth. After a short stay in the mother country they were sent home whitewashed. These walking lies had nothing left to say to their brothers...

Although it may be harsh to class Senghor among Sartre's "walking lies"3 that have nothing to say to contemporary Africa, for our research purposes, he is theoretically significant to the problematique of postcolonial identity because his self-assimilation into the French ways was not a mere incidence of being autonomously acculturated by a pervasive colonial culture, his was a conscious intellectual programme ${ }^{4}$ that

2 http://www.unesco.org/bpi/eng/unescopress/96-186e.htm (accessed 20 October 2014).

3 Sartre's comment is sensible within the utility of his concept of "bad faith", the self-deluding inauthentic Self (see Being and nothingness, Sartre 2003: 70-93). 
even extended to aspects of his political praxis as a leader of a postcolonial African state. We will thus argue that beyond his talent and accomplishments as a poet in an adopted language, he controversially established himself as a theorist of cultural universalism that privileged a French-led globalism.

This paper is structured in a sequence that firstly constructs a portrait of Senghor within the theoretical context of the clash between African postmodernity, defined as African consciousness expressing its self-distinction from colonial epistemic values, and the persistence of Western modernity in the psyche of a postcolonial African selfhood (African modernity or coloniality). It is within this context that the pivotal concept of globalism is critically explicated, with a concluding charge of proto-globalism levelled against Senghor's political praxis. The critical nub of our explication of globalism, as the self-imposition of a particular cultural apparatus as being necessarily universal and innately normative is aided by: Paul James's critique of globalisation, Walter Mignolo's anti-colonial anti-universalism and Paulin Houtondji's critical literary theory. These, bar James, are introduced in the concluding sections in corroboration of our charge against Senghor.

Senghor's assimilationist tendencies are outlined through his literary-intellectual biography as the premise towards our conclusion. This biographical reconstruction constitutes the body of our discussion. We thus develop a reflective critique around Senghor that goes beyond him as a person, to point out issues, questions and dilemmas raised by the rise of philosophical, cultural and technological Afrocentricity from the ashes of colonial epistemicide. The kind of self-identity and social ontology that should emerge in tandem with a revolutionary African consciousness, as well as the philosophical challenges these portend, is our primary interest. ${ }^{5}$

\section{THEORETICAL CONTEXT: ON GLOBALISM}

The discussion in this paper is governed by a view on Africa and Africanity that we need to declare upfront. This view holds that Africa is a geo-political construct, what Paul James would call an imaginary (James and Steger 2010: xi), in the same way as we have an imagination of a global world community. This relativisation of the political ontology of Africa resonates the subject of Ali Mazrui's The Africans: A triple heritage (1986) and Velantin Mudimbe's The idea of Africa (1994).

In this instance, we think of African consciousness as an expression of a cultural self-differentiation from other culturally-formed geo-political consciousnesses. In tandem, we maintain that blackness, a skin pigmentation, is a phenotypical reality that is empirically associated with Africa; it has little to do with African

5 Related to this, is our interest in the life and intellectual as well as political conduct of African luminaries, WEB Du Bois (1868-1963), the first African-American to graduate from Harvard University, and John Tengo Jabavu (1859-1921), the first black South African to become a university professor. 
consciousness. It is possible to be black, and to disdainfully disavow association with Africa (Tiger Woods?). Black selfhood (black consciousness) is a subjective existential consciousness that self-differentiates itself against its negation by other racial selfhoods. European white selfhood, due to the incidence of the history of colonisation, happens to be the primary conceptual antithesis of African black selfhood. Within this context, a critical discussion of globalisation and the concomitant promotion of Western universalism cannot be left at the abstract level of an internationalist political ethic, as Senghor's admirers tend to do. The historicocultural context of the grievance of African selfhood by European colonialism, and the struggle for the recovery of this Self within a community of geo-politically constructed Selves (vid. Nabudere 2011: ad passim), is critical to our disquisition.

In a speech at his induction ceremony to L'Académie française in Paris, Senghor, inter alia, ominously opined: "From century to century, here and abroad, France adopts values that at first appear foreign. Then she assimilates them to create a new form of civilisation, moving forward the universal” (Senghor 1991: xxii). Building on the theme of the universalisation of nationally constructed civilisations, the Academy's president, Edgar Faure, responded by hailing Senghor as "incarnating the life of Africa and the world" (Senghor 1991: xxii). The critical question we are to consider is: Is this embrace of the self-mutation of an imperial culture into the bulwark of a universal ethic that appears to be in amity with African selfhood, as incarnated in the praxis and corpus of Senghor, what should constitute authentic postcolonial African consciousness in the globalising world?

Viewed against current twenty-first century thinking wherein culture and national identity are threatened by the hegemonic imaginary of globalisation, the foregoing statements on universalism, or specifically the proffered universality of the French way, are of critical interest to us. This Zeitgeist that seeks to promote a consciousness of commonality and oneness among the peoples of the globe, already nascent in Senghor's 1980s, is uncomfortable with, and discourages discourses on the challenges faced by postcolonial African self-identity. The self-assertion of African identity and the quest for the recovery of the downtrodden African heritage against the march of the universalising "culturally superior" Western modernity, is viewed as retrogressive, parochial and racialist. "We are being asked to think 'beyond identity', when for many of us identity remains a quest, something in-the-making”, laments Amina Mama (Melber 2001: 9).

The emergent assertion of Africanity and black selfhood is significant as it is one of the global trends that constitute what Martin Jacques (2012: 17) has aptly identified as the definitional feature of this epoch of globalisation, namely "a clash of modernities". For our purposes, Senghor's life and intellectual conduct present a useful challenge within the context of a strife between the immanence of Western culture over Africa (Euro-North American modernity), and the self-assertion of the 
apparatus of African epistemic inventories that seek to understand and confront the world from an African vantage point (African postmodernity).

Our point of departure, therefore, is a claim that African postmodernism is not only constituted by a critical awareness of colonial European cultural imperialism as an event that has disfigured African self-image and expression, but that it is principally a hostile detection of the self-imposition of Anglo-Saxon and North American value systems and thought-forms as universally normative on all that constitutes the good life. This view of African postmodernity as being centrally ethno-critical, and therefore as an expression of the struggle for the liberation of the epistemic potentiality of Africa, poses itself as a conceptual framework for a critique of the assimilationist profile that characterised Senghor's relationship with colonialism. It is a critique of an African modernism that is essentially an Afrocoloniality. To the degree that our critique has as its intention the service of the emancipation of African self-expression and self-actualisation from the hegemonic pro-colonial cultural inventories of Euro-North America, it is Africanist. It is not merely a critique emanating from Africa; that is, it is not merely African; it is a reaction against a tendency that bodes ill for the prospects of a culturally and politically sovereign Africa.

The globalism we claim Senghor was unwittingly a precocious expression of, needs to be differentiated from the concept of globalisation. Globalism is an ideology of globalisation (James and Steger 2010: Xv). It is an attitude or policy that places the interests of the entire world above those of an individual nation or group of persons on the pretext that this external over-imposition is natural and necessary. This is a version of what Michel Foucault decried as "a tyranny of identity" whereby a universal normative identity is imposed upon "the individual in his deference" (Rosen 1987: 192). Although much of the concept has developed within the critique of capitalistic neo-liberalism as market globalism (Steger 2009), our intention is to isolate cultural globalism, particularly insofar as it impinges on geo-politically constructed identity. The historical factor of European colonialism, of course, sharpens this out as the tension between the immanence of European globalism upon the geo-political self-identity of an emergent Africa.

In our times we have come to know that cultural globalism manifests itself as the discursive network of European and North American ideas and practices being enforced militarily and otherwise as "the way of life". However, globalism's main import is the myth of the necessity and value of homogenisation of cultural expressions and intellectual inventories, whereby it is, for instance, argued that the worldwide spread of the English or French language serves a valuable globalising function that is necessary for world citizenry. This "world citizenry" that has to feed on enforced global commonality and standardisation of cultural inventories is famously expounded by Jürgen Habermas (2001 [1998]) and elements of the "global civil society” who have given themselves the task of developing some transcultural 
concept of a "global enlightenment". Upon closer examination, however, a promotion of this "global enlightenment" tends to be an attempt to save the remnants of a European intellectual heritage in a de-Westernising twenty-first century.

Given this enunciation of our approach as well as conceptual clarifications, we can now proceed to critically explore Senghor's self-identity against this background of our view of the relationship between African modernity and Eurocentricism as a form of a postcolonial globalism visited upon Africa.

\section{THE FRENCH AFRICAN CULTURAL THEORIST ${ }^{6}$}

Born in Senegal in 1906, Senghor was availed the best of French Catholic mission education that led him to further studies in Paris, culminating at Sorbonne University where he graduated with philosophy and French literature. In 1932 he was granted French citizenship, and by 1935 he had become the first African in the history of France to acquire aggregation de l'Universite (licence) to teach grammar in a French public school system in Paris.

Having done the obligatory military service as a French citizen, at the outbreak of the Second World/European War he was drafted into the army during which period he was captured by the Germans in 1939, and spent 18 months as prisoner of war. While prisoner, he wrote poems which were later published in 1948 as Hosties Noires (Black Hosts). A dramatic poem in this anthology "To the Senegalese soldiers who died for France”, seminally betrays the foundational structure of Senghor's thinking on colonial rule. He salutes his fallen African compatriots and beseeches them to appreciate the comradeship shared with French soldiers and the place of their death (hosted by white pre-departed ancestors). They must rest with pride rather than anger that they died for France in a European war:

Ah! If I could one day sing in a voice glowing like embers,

If I could praise the friendship of comrades as fervent

And delicate as entrails, as strong as tendons.

Receive this red earth, under a summer sun, this soil

Reddened with blood of white hosts

Receive the salute of your black comrades,

Senegalese soldiers

WHO DIED FOR THE REPUBLIC! (in Senghor 1991: 46).

6 Biographical data herein presented without direct citation is a collation and interpretation of narrations, amongst others, by Hymans (1971); Vaillant (1990); Khaphoya (1994); and Dixon (in Senghor 1991). 
Around the mid-1940s Senghor's writings started displaying expressions of a psychological or spiritual discord between his black African roots and French persona. This discord, in our assessment, is best detected in his nostalgic and angry prayerful poem, "Snow in Paris" published in his 1945 Chant's d'Ombre (Shadow Songs). The poem is one of the few overtly political of his poetry. He makes a rare direct reference to the painful past of slavery, and the destruction of African civilisation by colonial rulers ("They tore down the black forest to build a railroad/They cut down Africa's forests to save Civilisation/Because they needed human raw material”). Significantly though, the poem elicits his trademark style, namely the invocation of the mystical, which is often the syncretic mix of the African indigenous religion of his childhood and his Catholicism. In this poem, written on Christmas Day, we hear:

Lord, you have visited Paris on this day of your birth

Because it has become mean and evil,

You have purified it with incorruptible cold, with white death.

And now my heart melts like snow in the sun.

I forget

The white hands firing the rifles that crumbled our empires,

The hands that once whipped slaves, and whipped you,

The snowy hands that slapped you,

The powdery hands that slapped me,

My heart Lord, has melted like snow on the roofs of Paris

In the sunshine of your gentleness.

It is kind even unto my enemies and unto my bothers.

The time around the writing of this poem marks the period of his immersion in the French postwar leftist intellectual ferment which brought him into contact with the likes of Andre Gide, Albert Camus, and Jean-Paul Sartre. He even managed to convince Sartre to write an introduction, the soon to be famed "Orphée Noir", to his 1948 collection showcasing the French language poetry of black artists from Africa and Madagascar. ${ }^{7}$

But it was his friendship with Aimé Césaire, Franz Fanon's teacher who in 1939 had coined the term Négritude in the context of his poem Cahier d'un retour aus pays natal (Notebook of a return to the native land), that was to define Senghor's profile in history. With Léon Damas they established themselves as key proponents of an artistic and literary genre that was devoted to redeeming expressions of livedAfrican-experience from denigration by the blacks themselves, and the wider world.

7 Anthologie de la nouvelle poésie négre et malgasche de langue française (1948). 
His mission during this period of his life was to challenge his Caribbean fellow black artists that they are African, and that they should appreciate the value of their Africanity, take pride in it, and display it to the world.

In 1945 he was elected to the French Constituent Assembly, and from 1948 until 1958, he was Senegal's representative in the French National Assembly. It was during this period that he briefly represented France at UNESCO, and at the European Assembly in Strasbourg.

In 1957, having divorced Ginette Ebouié, daughter of the black Governor General of the French Equatorial Africa (AEF), he married Colette Hubert of Normandy. Khapoya notes that "it is striking that in Senghor's autobiography, there is no mention of the fact that he is married to a French white woman” (Khaphoya 1994: 122). This, of course, to his internationalist consciousness, was not worth noting. Contrasting this occurrence with the British intrigue and international furore that accompanied Botswana's Seretse Khama's marriage of Ruth Williams in England around the same time, Khaphoya (1994: 123) notes:

Senghor's marriage to a white woman caused no ripple, no negative excitement at all in France. It was as though the French had expected all along that Senghor, as a fine selfrespecting Frenchman, albeit with African ancestry, would marry a French woman.

Melvin Dixon, the English translator of Senghor's The collected poems (Senghor 1991), testifies Senghor often stated during their conversations that all great civilisations in history, from Ancient Egypt and Greece, as well as the Americas, have been "Civilizations of mixed-blood, biologically and culturally" (Dixon, Senghor 1991: xxii). Based on this view, he deeply believed in the cross-fertilisation of cultures, even between colonial and anti-colonial cultures. His theory of cultural cross-fertilisation, however, in our analysis, carried an unexpressed view that the European cultural chromosome is overwhelmingly superior to the African one. In 1961 he published Chants pour signare (Dixon, in Senghor 1991: 121), a long poem written in joint tribute to both his African ex-wife and Mrs Collette Hubert Senghor. Titling the poem "Songs for signare", he adopted the metaphor of the mixed-race women, called signare by the Senegalese, who had often ended up as mistresses of white colonial administrators, as an allegory of the cultural assimilation of peoples that he believed France rightly promoted (Dixon, in Senghor 1991: xxiv).

After stepping down as President of Senegal in 1981, Senghor retired to France where he died on 20 December 2001.

\section{SENGHOR'S NEGRITUDE AND EPISTEMOLOGY}

The life of Senghor, credited by history as one of the founders of the revolutionary philosophy of Negritude, remained trapped in a conflict between his admiration of African heritage, on the one hand, and on the other, in his belief in the prototypology 
of the French culture, the hegemonic intentions of whose universalism he promoted. In our view, he managed to live with the anguish generated by these conflicting ideals by finding refuge in a mystical epistemology which his poetic talent facilitated. In this regard, Irele's view that "Senghor's theory of Negritude developed as a function of his poetic vocation" is instructive (Irele 2002: 115).

For him, Negritude was simply the sum total of the cultural values of the African civilisation that had to be preserved and revitalised for active contribution to the global dialogue of cultures. Accordingly, his affiliation to Negritude would not go all the way to a radical analysis of French racism and the rejection of assimilation into Frenchhood, a path taken by Césaire, and later represented by Fanon. Fanon would later dismissively declare that "African culture will take concrete shape around the struggle of the people, not around songs, poems or folklore" (Fanon 1963: 164).

The difference between Senghor's version of Negritude and that of, for example, Fanon, is best captured in the speech of the UNESCO Director General, Frederico Mayor on the occasion of the latter's ninetieth birthday celebration referred to earlier, in these words:

But when, in the splendour of his adopted language, he lays claim loudly and clearly to his African identity, it is never in a spirit of introversion, withdrawal or refusal of otherness. His Negritude is, as he himself says, a 'trowel in the hand' and is proclaimed in order to create rather than negate, to define himself in relation, not in opposition, to the Other ${ }^{8}$.

Mayor concluded his birthday address with a poem that Salah Stétié had dedicated to Senghor, which ironically, when interpreted in its original context, turns out to be a candid agony about what Senghor was about.

Tomorrow we shall all be black or we shall not be

Tomorrow we shall all be white or we shall not be

We shall be yellow, we shall be red, and we shall be

those fine half-castes in heart and soul, rejoicing in the rainbow.

We shall, Senghor, possess your Negritude

In order to possess your vastitude and our own. (ibid)

Senghor's re-valorisation of African heritage tended to be an exercise in the repackaging of the latter for acceptance and appreciation by the "civilised world". In his introduction to The collected poems, Dixon observes that Senghor's poems are obsessed with presenting a positive image of Africa to his adopted European nation. Even in his highly sensual and provocative imagery in his famous "Black woman", the historical reality of Africa who could be presented as a resourceful mother is lost in his desire to sell black femininity to his French readership. "Very little in the poem offers a contemporary revitalisation of Africa, but the poem provides instead

8 http://unesdoc.unesco.org/images/0010/001044/104487e.pdf (accessed 20 October 2014). 
a modern reconstruction of blackness for intercultural consumption” (Dixon, in Senghor 1991: xxx).

This preoccupation with an external audience included the apologistic extolling and demonstration of the rational cogency of the African way of apprehension of life and intellectual self-expression. This Senghor famously presented in these terms:

We consider the Negro-African as he faces the Other: God, man, animal, tree or pebble, natural or social phenomenon. In contrast to the classic European, the Negro-African does not draw a line between himself and the object, he does not hold it at a distance, nor does he merely look at it and analyse it. After holding it at a distance, after scanning it without analysing it, he takes it vibrant in his hands, careful not to kill or fix it. He touches it, feels it, and smells it. The Negro-African is like one of those Third Day Worms, a pure field of sensations...Thus the Negro-African sympathises, abandons his personality to become identified with the Other, and dies to be reborn in the Other. He does not assimilate; he is assimilated. He lives a common life with the Other; he lives in a symbiosis (Senghor 1964 [1959]: 72).

With his view of an intuitional, and notorious "Emotion is Negro; Reason is Greek" philosophy (Mphahlele 2004: 51), Senghor crafted an aesthetic epistemology that sought to prove to the world that the African's holistic way of feeling, as a way of knowing, is not inferior to the detached logic of the Westerner. "White reason is analytic through utilisation; Negro is intuitive through participation", he maintained (in Hallen 2009: 72).

\section{SENGHOR'S POLITICAL PRAXIS}

Soon after returning to Africa in 1961 and assuming the office of President of Senegal, Senghor turned Dakar into a centre of Francophone Africa's intellectual, cultural and literary production; the then ensuing Pan-African struggle for political selfdetermination from colonial rule seemed not to be one of his priorities. This fact is attested by our earlier reference to Mandela's biographical comments. He continued his cultural and philosophical activism on themes that had no direct bearing on the broader struggle for the decolonisation of Africa. His poetry since 1956 (from publication of the Ethiopiques) veered more and more from overtly political issues to the surreal and romantic, producing verses on the sensuality of African femininity ("Black woman"), and poems on "New York" and "Blues" (Dixon, in Senghor 1991: xxxi).

Senghor's political philosophy was premised on an embrace of the notion of the exceptionalism of French colonial rule in Africa, as Michael Crowder (1962) ably explains in his Senegal: A study in French assimilation policy. The French had succeeded in inculcating the myth that they were not like other colonial plunderers of Africa among the French colonial communities. They presented themselves as keen to extend an altruistic guiding hand throughout the various economic and political 
developmental stages of emergent Africa. As the first head of state of what had been France's seat of colonial administration in West Africa, Senghor was to play an enduring role in France's success in embedding this exceptionalism in its foreign policy doctrine on Africa.

In a perplexing manner, his state-craftmanship of a postcolonial Senegal was based on an eclectic mix of self-serving totalitarianism that was buttressed with elements of a pre-Marxian French socialism, which he promoted as African Socialism (Friedland and Rosberg 2006: 264-277). To this decidedly “non-scientific” Marxism, that expressly distanced itself from the Soviet Union-led international communist movement, he infused the nativistic elements of his understanding of Negritude. In a public lecture delivered at Oxford University on "African socialism" in 1961 he assertively declared:

But our socialism is not that of Europe. It is neither atheistic communism, nor the democratic socialism of the Second International... We have modestly called it the African Mode of Socialism... We are forced to seek our own original mode, a Negro-African mode... We have decided to borrow from the socialist experiments only certain elements (in Friedland and Rosberg 2006: 264).

For him, socialism was about leveraging the traditional African way of understanding how society is to be organised, and using this to defend his unique brand of African epistemology in the process of justifying the affinity of African culture with socialism. This is expressed in On African socialism (Senghor 1964). This provoked a comprehensive critique from Kwame Nkrumah in his famous Cairo Lecture, African socialism revisited (Nkrumah 1967).

Based on the foregoing brief consideration of Senghor's philosophy and mission in life as a politician committed to the French course, we propose that deeply veiled in his rejection of Marxism as propagated by the Second International, was a discomfort at communism's ideal of a geo-political universalism which was in competition with the universalism of the "humanistic" Western Marxism. A direct attack of the universalism of Soviet communism on the basis of it being a threat to its Cold War nemesis of French imperialism, is hidden in Senghor's exaggerated extolling of the humanism he claimed African culture is emblematic of. This led Nkrumah in his Cairo paper to remind Senghor that pre-colonial Africa was not a modicum of the holiness of human kindness; that Africans traded each other as slaves even before the formal outbreak of the Trans-Atlantic slave trade (Nkrumah 1967).

In 1977, three years before stepping down from his 20 years as President of Senegal, Senghor published Négritude et civilisation de l'Universel (Negritude and Universal Civilisation, Senghor 1977). Here he persistently argued that within Negritude (African culture?) as a civilisation, there is a quality of humanism that makes it worthy of universalisation. True to form, however, the work is replete with 
references to the source of its inspiration, Teillard de Chardin, a French Catholic priest and philosopher.

\section{FROM GLOBALISM TO AFRICAN SELF-EXPRESSION}

Our review of Senghor's political praxis draws us to the usefulness of Walter Mignolo's evaluative conceptual framework of "coloniality" as applicable to the history of decolonisation of Africa (Mignolo 2009: 1-23; 2011). Agreeing with the sentiment that "the decolonisation of Africa" is the most potent myth of our times (see Grosfoguel 2007: 211), that Africa remains culturally in a state of coloniality, we find the concomitant normative concept of decoloniality pertinent in interpreting Senghor. Because "Eurocentrism is not a geographic but an epistemological problem", as Mignolo (2013) asserts, decoloniality as an intellectual project that seeks to uncover the colonial matrix of power at all levels, all over the globe, becomes imperative. It is, in particular, epistemological, and as such serves as a potent analytical expression that focuses on the mind, consciousness, and ultimately African assertive self-knowledge and identity. It is with the decoloniality prism that we read Senghor.

Our thesis is on the question of the extent to which the colonial epistemic and cultural system that typically masquerades as universal and global is to be accommodated, assimilated or rejected by Africans as postcolonial subjects. As a critical enquiry on the nature and content of African modernity, that is, postcolonial African self-expression, we propose that the degree at which authentic Africanity, that is being-for-Africa, is expressed, can only be within an epistemic spectrum that ranges between coloniality and decoloniality. Coloniality, aptly, refers to the psychoepistemic consequences of colonial rule and tutelage that subsist even after the politico-juridical manifestation of colonial rule has been shut down on "Independence Day". This is best expressed by Sabelo Ndlovu-Gatsheni in these terms:

Transcending the edifice of Euro-North American modernity, particularly its globalised grammars, and rhetoric has proven to be a major challenge for Africans, breathing as they do, modernity and coloniality every day. The institutions that were bequeathed by modernity on the world have somehow been naturalised. Euro-normativity has routinised and naturalised itself. Euro-North American epistemology has been globalised. African minds have been colonised (Ndlovu-Gatsheni 2014: 36).

Within the spectrum of African consciousness referred to above, therefore, the base of coloniality is an indication of entrapment in mental slavery, and the range from thence is a leap into an epistemic realm of decoloniality, a dissident mentality eversuspicious of Western cultural expansionism in all its forms and manifestations. It is in this sense that "decoloniality" is conceptually analogous to our usage of African postmodernity. It signifies a critical re-evaluation of African modernity as the historical sum of colonisation. 
This reflection on the crisis of African modernity and the possible logical conclusion of the disavowal of the Westernism of much of prevailing anti-colonial discourse has agonised African scholars for decades, as evidenced, inter alia, by Kwame Gyeke's Tradition and modernity: Philosophical reflections on the African experience (Gyeke 1997) and various works of Nkrumah (e.g., 1964). The difference between our approach and the latter body of writings is our endeavour to deal with the epistemological challenges occasioned by the clash between colonial and postcolonial modernities. In the 1967 address referred to earlier, in which he takes into account Senghor's work, Nkrumah conclusively and pragmatically conceded:

When one society meets another, the observed historical trend is that acculturation results in a balance of forward movement, a movement in which each society assimilates certain useful attributes of the other. Social evolution is a dialectical process; it has ups and downs, but, on balance, it always represents an upward trend.

While Nkrumah leaves room for Senghor's theory in arguing that a given society naturally assimilates influences from others, Mignolo's and our emphasis will be that the content of what is assimilated must be interrogated. If it is culture-epistemological, it must be approached with assertive suspicion. If what is assimilated is presented or presents itself as being universal, its claims to universality, globalism, must be rejected. To this end, Mignolo coined the concept of pluriversalism, which in reaction against Western universalism, demands a "plural sensibility towards global knowledge" (Mignolo 2013). Pluriversalism calls for an accord of equal value and status to all traditions and modes of thought in a globalising world.

It would in this context have been expected of Senghor to have demanded that his indigenous Serer language and art forms should have an equal place and focus for promotion alongside the French language, a demand Ngugi wa Thiong'o (1986) exposits in Decolonising the mind: The politics of language in African literature. Such a demand, which moves a degree beyond Mignolo's multiculturalist pluriversalism, would in the African historico-political context have assumed a more pointed revolutionary dimension; it would have been a defiant assertion of and promotion of Africanity. What did he deem corrigible in his native language that he could not use it to promote his artistic talent?

The answer is found in Hountondji's (2002b: 126) lament on how African thinkers and writers are forever obsessed, if not forced, to articulate themselves in thought-forms that resonate with the mental dispositions of their European and North American audiences. This he, and thinkers such as Archie Mafeje (2011) at CODESERIA, famously termed an exogenous demand in African literature, the opposite of what is needed, namely, endogenous communication, whereby Africans must communicate as Africans, and only let the Other to join into their own selfexpression (Hountondji 2002a: 27-29). The exogenous attitude is the inversion of the Self versus Other relationship. It illegitimately places the interests of the "Other" 
before those of "Self". Self-realisation and self-development is sacrificed at the altar of a distorted imaginary of globalisation and human universality. In the case of Senghor, as we observed, his African-self was sacrificed for French civilisation.

In line with a plausible Hountondji critique, Dixon further states that throughout his poetry, "Senghor instructs and prepares his audience to receive blackness...[his] poetic method depends on the otherness of his audience - or at least the environment of cultural differences - to which he introduces and recasts race. Senghor's reach for cross-culturalism becomes his practice of universalism” (Dixon, in Senghor 1991: $\mathrm{xxx}$ ).

In contradistinction to this exogenous trend, we find Jéan-Paul Sartre, conscious of his socio-cultural position as a European, being forced to start off his Preface to Fanon's The wretched of the Earth with the headline sentence: "This book had no need for a preface, especially since it is not addressed to us (colonial Europeans). I have written one, nevertheless..." (Sartre, in Fanon 1963: 2), and hastens to poignantly extol the endogenous nature of Fanon's writing:

Europeans, you must open this book and enter into it. After few steps in the darkness you will see strangers gathered around a fire; come close, and listen, for they are talking of the destiny they will mete out to your trading posts and mercenaries who defend them. They will see you, perhaps, but they will go on talking among themselves, without even lowering their voices (Sartre, in Fanon 1963: 11).

\section{CONCLUSION}

In self-situating his consciousness within the French hermeneutic horizon, Senghor, as an artist and theorist fell into the trap of exogenous expression. Consequently, he failed to realise the inherent goal of Negritude which was to call attention to the selfassertion of black culture as an anti-systemic outburst against a hegemonic cultural apparatus that was aiding the more overt political and economic plunder of Africa. An embrace and intellectual loyalty to a Euro-Franco epistemic framework without a conscious demand that the whole of the African culturo-ethical inventory should be accorded parity of status with white European cultural aspirations in a cosmopolitan world, is inexcusable for an African intellectual legend of Senghor's stature.

The appointment to the French Academy was not the only poignant recognition of Senghor's kinship with French culture. The fact that Senghor had in the prime of his life comfortably rose within the formal French political system to the level of even being appointed as France's official representative to UNESCO, indicates the extent of the faith he had in the French cultural system. Even within the defined context of the colonised Africa of the pre-1960s, this professional promotion of the French way of life at a United Nation's institution, was nothing but plainly globalist, hence our contention that Senghor, despite his celebrated contribution to the formulation of the philosophy of Negritude, was a proto-globalist. In Senghor, we note a fatalistic 
embrace of a colonial cultural and intellectual inventory as not only the assumed mode of anti-colonial discourse, but also as the trusted motor for universal human progress, in this case: the "French way" consumed as the "taken-for-granted social ontology" of postcolonial Africa selfhood.

\section{REFERENCES}

Crowder, M. 1962. Senegal: A study in French assimilation policy. London: Oxford University Press.

Fanon, F. 1963 [1961]. The wretched of the Earth. New York; Grove Press.

Friedland W. and Rosberg, C.G.(eds). 2006. African Socialism. Stanford: Stanford University Press.

Grosfoguel, R. 2007. The epistemic decolonial truth: Beyond political-economy paradigms. Cultural Studies (21)11: 23-34.

Gyeke, K. 1997. Tradition and modernity: Philosophical reflections on the African experience. New York: Oxford University Press.

Habermas, J. 2001 [1998]. The postnational constellation: Political essays (Studies in contemporary German social thought). Translated by Max Pensky. Boston: Mit Press.

Hallen, B. 2009. A short history of African philosophy (2nd edition). Bloomington: Indiana University Press.

Hountondji, P. 2002a. The struggle for meaning: Reflections on philosophy, culture and democracy in Africa. Ohio: Ohio University Press.

Hountondji, P. 2002b. An alienated literature. In Philosophy from Africa: A text with readings ( $2^{\text {nd }}$ edition). Edited by P.H. Coetzee and A.P.J. Roux. Cape Town: Oxford University Press, 135-136.

Hymans, J. 1971. Léopold Sédar Senghor: An intellectual biography. Edinburgh: Edinburgh University Press.

Irele, F. 2002. Francophone African philosophy. In Philosophy from Africa: A text with readings ( $2^{\text {nd }}$ edition). Edited by P.H. Coetzee and A.P.J. Roux. Cape Town: Oxford University Press, 112-119.

James, P. and Steger, M.B. (eds). 2010. Globalisation and culture, Vol. 4, Ideologies of globalism. London: Sage Publications.

Jacques, M. 2012. When China rules the world: The end of the Western world and birth of a new global order (2nd edition). London: Penguin.

Khaphoya, V. 1994. The African experience: An introduction. Englewood Cliffs: Prentice-Hall.

Mafeje, A. 2011. Africanity: A combative ontology. In The Postcolonial turn. Edited by R. Devisch, F. Namnjoh. Bamenda: LANGAA, 31-44.

Mandela, N. 1994. Long walk to freedom. London: Little Brown.

Mazrui, A. 1986. The Africans: A triple heritage. London: Little Brown.

Melber, H. (ed.). 2001. Identity and beyond: Rethinking Africanity. Uppsala: Nordiska Afrikainstitutet. 
Mphahlele, E. 2004. Es'kia Continued. Johannesburg: Stainbank \& Associates.

Mignolo, W. 2009. Epistemic disobedience, independent thought and decolonial freedom. Theory, Culture and Society 26(7-8): 1-23.

Mignolo, W. 2011. The darker side of Western modernity: Global future, decolonial options. Duke University Press.

Mignolo, W. 2013. Modernity and the plural vision. Interviewed by Christopher Lee, Johannesburg. Mail \& Gaurdian 30 August, p. 16.

Mudimbe, V. 1994. The idea of Africa. Bloomington: Indiana University Press.

Nabudere, D. 2011. Afrikology: Philosophy and wholeness - An epistemology. Pretoria: Africa Institute of South Africa.

Ndlovu-Gatsheni, S. 2014. Eurocentrism, coloniality and the myths of decolonisation of Africa. The Thinker Q1: 34, 36.

Nkrumah, K. 1964. Consciencism. London: Heinemann.

Nkrumah, K. 1967. African socialism revisited. Paper read at Africa Seminar in Cairo. https:// www.marxists.org/subject/africa/nkrumah/1967/african-socialism-revisited.htm (accessed 26 May 2014)

Rosen, S. 1987. Hermeneutics as politics. Oxford University Press.

Sartre, J-P. 2003 [1943]. Being and nothingness. Oxford: Routledge Classics.

Senghor, L.S. 1948. Anthologie de la nouvelle poésie négre et malgasche de langue française.

Senghor, L.S. 1964 [1959]. On African socialism. Translated with an introduction by Mercer Cook. London: Pall Mall Press.

Senghor, L.S. 1977. Négritude et civilisation de l'Universel (Liberte 3). Paris: Seuil.

Senghor, L.S. 1991. The collected poetry. Translated with an introduction by Melvin Dixon. Charlottesville: University Press of Virginia.

Steger, M. 2009. Globalism: The new market ideology. Lanman: Rowman \& Littlefield.

Thiong'o, N. 1986. Decolonising the mind: The politics of language in African Literature. London: Heinemann Educational.

Vaillant, J. 1990. Black, French, and African: A life of Léopold Sédar Senghor. Cambridge, Mass.: Harvard University Press. 